\title{
SUNSCREEN CREAM BASED ON LOCAL RAW MATERIALS OF Sonneratia alba FROM TARAKAN CITY
}

\author{
Gloria Ika Satriani $^{1}$. Burhanuddin Ihsan ${ }^{1} \cdot$ Yulma $^{2}$. \\ Rukisah $^{1}$
}

Ringkasan Traditional products derived from the local wisdom of the Tarakan City coastal communities, namely in the form of cold protective skin powder from the sun which is made from mangrove raw Sonneratia alba. This product has potential to be developed to improve the economic value of local communities. They can compete with products other sunscreen products produced by industry (commercial) through cream preparation technology (sunscreen).This research was carried out for seven months (February-August 2018) in the Environmental Laboratory of FPIK UBT, Samarinda Pharmacy laboratory (AKFARSAM), and the UNMUL Mathematics and Biochemistry laboratory. The research procedure used maserasi method with $70 \%$ ethanol solvent followed by concentrating the extract using a rotary evaporator to obtain extracts of active ingredients and carried out qualitative phytochemical testing. The obtained active ingredient was is then formulated into a sunscreen cream preparation. The level of protection of mixed sunscreen cold powder and commer-

\footnotetext{
$\left.{ }^{1}\right)$ Jurusan Akuakultur FPIK UBT ${ }^{2}$ )Jurusan Manajemen Sumberdaya Perairan FPIK UBT

E-mail: gloria.ubt@gmail.com
}

cial cream were tested by using $U V$ VIS spectrophotometer to see the value of Sun Protection Factor (SPF) at absorbance of 290-320 nm. Qualitative phytochemical test showed that on S.alba contains of positive alkaloids, phenols, flavonoids, steroids, and tannins, and negative saponins. ANOVA statistical analysis (95\%) based on the calculated $F$ value $<F$ table so that $H 1$ is rejected and $\mathrm{HO}$ is accepted, ie there is no difference in SPF values among sunscreen products tested in this stu$d y$. Based on the category of sunscreen ability, it is known that the SPF value of the three different products tested in this study ranged from maximum to ultra categories with $\mathrm{pH}$ values ranging from 6.5-7.5.

Keywords Cold protective skin powder, phytochemical, sun protection factor (SPF)

Received : 15 September 2018

Accepted : 20 Oktober 2018

\section{PENDAHULUAN}

Sudah sejak lama, secara turun temurun masyarakat nelayan di Kota Tarakan, khususnya kaum ibu-ibu (istri ne- 
layan lokal) senantiasa menggunakan pupur/bedak dingin ketika beraktivitas siang hari (outdoor) terutamasaat sinar matahari terik dan udara sangat kering. Pupur/bedak dingin tersebut umumnya dibalurkan ke seluruh wajah sehingga ketika mengering akan menghasilkan tampilan wajah seperti menggunakan topeng putih tebal. Khasiat penggunaan pupur/bedak dingin yang dipercaya oleh ibu-ibu nelayan lokal setempat ialah mampu membuat kulit wajah mereka tetap sejuk, lembab, dan mengurangi dampak buruk sinar matahari yang dapat menyebabkan kulit berubah menjadi semakin coklat atau menghitam (gosong). Pupur/bedak dingin tersebut dibuat sendiri secara tradisional dengan menggunakan racikan yang terdiri dari bahan baku lokal diantaranya bahan mangrove tanaman $S$. alba (baik dari kulit, batang, bunga, buah, daun, dan biji) yang dipercaya dapat memberikan khasiat untuk mengurangi dampak buruk paparan sinar matahari siang yang terik. Masyarakat lokal Indonesia umumnya memiliki kekayaan sumberdaya alami yang telah digunakan secara turuntemurun khususnya tumbuhan kosmetik tradisional yang memiliki potensi bahan aktif kosmetik (Darmakusuma, 2014).

Kearifan lokal yang dimiliki masyarakat setempat (ibu-ibu nelayan Suku Asli Tidung) perlu dilestarikan dan dikembangkan serta didukung dengan kajiankajian ilmiah penelitian agar manfaatnya dapat terus dirasakan, dan memiliki nilai tambah (ekonomi). Produk tradisional berupa bedak/pupur dingin ini berpotensi untuk dikembangkan guna meningkatkan nilai ekonomi masyarakat lokal, dan dapat bersaing dengan produk-produk tabir surya lainnya yang dihasilkan oleh produksi industri (pabrik). Menurut keputusan Kepala BPOM RI (No: HK. 00. 05. 42. 1018) menyatakan bahwa pengertian bahan tabir surya ialah bahan yang digunakan untuk melindungi kulit dari radiasi sinar UV dengan cara menyerap, memancarkan, dan menghamburkan.

Bahan baku yang relatif ramah lingkungan sangat mudah diperoleh di Kota Tarakan, yakni tanaman S. alba menjadi nilai tambah tersendiri bagi pengembangan bedak/pupur dingin menjadi sediaan krim tabir surya. Sebagian besar aktivitas farmakologis suatu tumbuhan berkaitan erat dengan kandungan metabolit sekundernya. Metabolit sekunder adalah kelompok senyawa yang dihasilkan tumbuhan dengan fungsi yang hingga saat ini belum diketahui dengan jelas, namun diduga kuat berkaitan dengan kemampuan tumbuhan untuk mempertahankan diri dari serangan hama dan penyakit (Yadav and Agarwala, 2011).Penelitian terbaru menemukan bahwa kanker tenggorokan dapat disembuhkan melalui aktivitas berkumur menggunakan ekstrakyang berasal dari kulit mangrove (Revathi et al., 2013). Hingga dengan saat ini, masih terus dilakukan pembuktian ilmiah tentang manfaat dari aktivitas metabolit sekunder yang dihasilkan oleh tanaman mangrove khususnya buah $S$. alba (apple mangrove) serta pembuatan produk turunannya. Penelitian ini merupakan produk tradisional hasil dari kearifan lokal yang ramah lingkungan karena menggunakan bahan alami (buah mangrove) dan melalui penelitian ini diharapkan dapat meningkatkan pemanfaatan, daya simpan, nilai tambah estetika, dan potensi ekonomi, serta mampu meningkatkan pemanfaatan "Buah Pedada (S. alba)" yang 
selama ini belum termanfaatkan secara optimal, sehingga menciptakan peluang bagi masyarakat untuk mendapatkan penghasilan dari menanam dan memelihara pohon mangrove jenis pedadadisamping ikut serta juga(secara tidak langsung) memelihara kawasan hutan mangrove yang memiliki nilai ekologis penting bagi ekosistem pesisir dan laut tropis khususnya wilayah Tarakan Kalimantan Utara.

\section{MATERI DAN METODE}

Ruang lingkup dalam penelitian ini adalah metode maserasi menggunakan pelarut etanol $70 \%$ dilanjutkan dengan rotary evaporasi. Pengujian fisik ekstrak S. alba (kadar air, kadar abu dan rendemen), pengujian fitokimia secara kualitatif (alkaloid, fenol, flavonoid, saponin, steroid, dan tanin) dan pembuatan racikan sediaan krim tabir surya berdasarkan IMO (2004) yaitu menimbang, mencampur, dan penapisan bahan sunscreen menjadi krim sediaan setengah padat berupa emulsi. Tahapan penelitian terdiri dari preparasi sampel, ekstraksi, uji fitokimia, peracikan sediaan krim dan penentuan nilai Sun Protection Factor (SPF). Penelitian ini dilaksanakan selama tujuh bulan (FebuariAgustus 2018) di laboratorium Lingkungan FPIK UBT untuk melakukan ekstraksi dan pengujian kualitatif fitokimia, laboratorium Farmasi Samarinda (AKFARSAM) untuk kegiatan meracik sediaan krim, dan laboratorium Biokimia MIPA UNMUL untuk melakukan pengujian nilai SPF.

Penentuan Nilai Sun Protection Factor (SPF) menurut Pissavini et al, (2003) adalah dengan menimbang sebanyak 1
Tabel 1 Kostanta Spektrum

\begin{tabular}{cc}
\hline Panjang gelombang $(\mathrm{nm})$ & $(\mathrm{EE}) \mathrm{x}(\mathrm{I})$ \\
\hline 290 & 0,015 \\
295 & 0,0817 \\
300 & 0,2874 \\
305 & 0,3278 \\
310 & 0,1864 \\
315 & 0,0839 \\
320 & 0,018 \\
Total & 1 \\
\hline
\end{tabular}

gram sampel dan dipindahkan ke dalam labu ukur dan ditambah etanol sampai $100 \mathrm{ml}$, dihomogenkan dan kemudian disaring menggunakan kertas saring. Sebanyak $5 \mathrm{~mL}$ larutan dipindahkan ke dalam labu ukur dan ditambah etanol sampai $50 \mathrm{~mL}$. Sebanyak $5 \mathrm{~mL}$ larutan dipindahkan ke dalam labu ukur dan ditambah etanol sampai $25 \mathrm{~mL}$. Spektrum absorbansi ditentukan dalam kisaran gelombang 290-320 nm dengan interval $5 \mathrm{~nm}$ dan menggunakan etanol sebagai blanko. Data absorbansi diperoleh dimasukan dalam Persamaan 1 berikut ini:

$S P F_{\text {Spek }}=F K x \sum_{290}^{329} E E(\beth) x I(\beth) x A b s(\beth)(1)$

dimana, FK/Faktor Koreksi (10); Abs/Absorbansi Sampel; EE(I)/Spektrum Efek Eritema; I(I)/Spektrum Cahaya Matahari

Nilai EE(】) x I(ב) adalah Konstanta yang ditetapkan oleh Sayre et al. (1979) yakni (Tabel 1)

Efektifitas tabir surya dinyatakan oleh Sun Protection Factor (SPF) yang didefinisikan sebagai perbandingan Dosis Eritema Minimum (DEM) pada kulit manusia terlindungi tabir surya dengan DEM tanpa perlindungan. Nilai SPF ditentukan melalui perbandingan energi dari sinar yang dipaparkan untuk dapat menimbulkan eritema (efek kemerahan pada kulit manusia) dan da- 
pat juga melalui waktu yang diperlukan sampai timbul eritema. Kategori kemampuan tabir surya menurut Damogalad et al. (2013)adalah minimal (24), sedang (4-6), ekstra (6-8), maksimal (8-15), dan ultra (>15). Hasil Perhitungan SPF pada penelitian ini menggunakan Spektrofotometer dengan mengamati tiga perlakuan (Pupur/Bedak Dingin, Sediaan Krim, dan Tabir Surya Komersil) yang masing-masing pengujian (Tabel 4) diulang sebanyak tiga kali menurut percobaan Rancangan Acak Lengkap (RAL) sebagai berikut ini (Persamaan 2):

$Y_{i j}=\mu_{i}+T_{i}+\varepsilon_{i j}$

dimana, $Y i j=$ Pengamatan ke $\mathrm{j}$ dari perlakuan ke $\mathrm{i} ; \mu_{i}=$ Nilai tengah umum; $\mathrm{T}_{i}=$ Pengaruh dari perlakuan ke i $\varepsilon_{i j}$ $=$ Galat percobaan dari perlakuan ke $\mathrm{i}$ pada pengamatan $\mathrm{ke} \mathrm{j} ; \mathrm{i}=1,2,3, \ldots \mathrm{t}$ adalah jumlah perlakuan; $\mathrm{j}=1,2,3, \ldots$. $\mathrm{r}$ adalah jumlah ulangan.

\section{HASIL DAN PEMBAHASAN}

Pada umumnya pelarut yang sering digunakan pada produk keamanan pangan adalah etanol pro analysis (etil alkohol $\mathrm{C}_{2} \mathrm{H}_{5} \mathrm{OH}$ ) karena etanol memiliki polaritas yang tinggi sehingga dapat mengekstrak bahan lebih banyak dibandingkan pelarut organik yang lain. Etanol ini adalah suatu jenis etanol dengan kadar $96,0-96,5 \%$ yang umum digunakan untuk industri farmasi dan kosmetik serta untuk minuman beralkohol. Etanol mempunyai titik didih yang rendah dan cenderung aman, tidak beracun dan berbahaya, namun larut dalam air dan melarutkan komponen senyawa organik seperti karbohidrat, resin dan gum (FDCA,
2002). Pelarut yang berbeda akan memberikan nilai yang berbeda karena pelarut akan berdifusi ke dalam sampel, serta pada proses tersebut pelarut terdifusi pada komponen yang memiliki tingkat kepolaran yang sama. Hal tersebut juga diutarakan oleh Sayre et al. (1979) bahwa faktor-faktor yang dapat mempengaruhi nilai rendemen yang dihasilkan yaitu metode ekstraksi yang digunakan, ukuran partikel sampel, kondisi dan waktu penyimpanan, lama waktu ekstraksi, perbandingan jumlah sampel terhadap jumlah pelarut yang digunakan, dan jenis pelarut yang digunakan.

Pemekatan ekstrak dilakukan dengan metode penguapan atau rotary evaporasi, yakni instrumen yang menggunakan prinsip destilasi (pemisahan) di mana terjadi proses perubahan molekul dalam fasa cair menjadi gas sehingga dihasilkan pemekatan ekstrak (Harvey, 2000). Prinsip utama ini menggunakan penurunan tekanan pada labu alas bulat dan pemutaran labu alas bulat sehingga pelarut dapat menguap lebih cepat di bawah titik didihnya. Ekstrak tersebut selanjutnya dikeringkan dengan oven (suhu konstan $40^{\circ} \mathrm{C}$ ) hingga menghasilkan rendemen ekstrak pasta kental.

Penapisan fitokimia ekstrak buah pedada (S.alba) dilakukan dengan uji alkaloid, fenol, flavonoid, saponin, steroid, tanin dan kadar total fenol (pada Tabel 2). Menurut Lim et al. (2002) bahwa ada hubungan antara total fenol dan aktivitas antioksidan dimana jika di dalam suatu bahan memiliki konsentrasi senyawa fenol yang tinggi maka aktivitas antioksidan dalam bahan tersebut juga tinggi. Andayani et al. (2008) menyatakan bahwa senyawa fenol dan aktivitas antioksidan memiliki gugus $-\mathrm{OH}$ 
dan -OR seperti flavonoid dan asam fenolat. Menurut Svobodová et al. (2003), senyawa fenolat berperan dalam menurunkan sinyal redoks-sensitif untuk menghambat kerusakan DNA.

Berdasarkan penelitian Herawati et al. (2011) ekstrak S. alba memiliki kandungan senyawa alkaloid, flavonoid, tripenoid, steroid, fenol hidrokuinon, saponin dan tanin. Berbeda dengan penelitian ini, bahwa ekstrak S.alba yang hidup di kawasan pesisir Pantai Amal Kota Tarakan pada pengujian kualitatif fitokimia menghasilkan nilai negatif yaitu tidak mengandung saponin. Perbedaan variasi genetik, geografi, iklim, teknik budidaya dan pemanenan, waktu penyimpanan, dan teknik persiapan ekstrak merupakan faktor penyebab perbedaan komposisi senyawa, khususnya metabolit sekunder, sehingga mempengaruhi kualitas senyawa ekstrak (Wu et al., 2009). Penelitian lain terhadap hasil analisis proksimat buah Sonneratia sp melaporkan bahwa buah tersebut memiliki kadar air (bb) 84,76\%, kadar abu (bk) 8,4\%, kadar lemak (bk) 4,82\%, kadar protein (bk) 9,21\%, dan kadar karbohidrat (bk) 77,57\% (Manalu, 2011).

Berdasarkan pengujian kadar air, kadar abu, dan rendemen terhadap sampel S.alba diketahui nilainya Tabel 3. Pasta kental ini selanjutnya diuji secara fisika terhadap kandungan kadar air dan kadar abu berdasarkan metode dengan tujuan untuk memberikan batasan minimal atau rentang besarnya kandungan air dan kadar abu dalam suatu bahan. Semakin kecil kandungan air dalam suatu bahan, maka akan sangat berguna untuk memperpanjang daya simpan pasta kental hasil ekstraksi selama penyimpanan. Sedangkan, penetapan kadar abu pasta kental dilakukan untuk memberikan gambaran kandungan senyawa anorganik yang terkandung dalam bahan, baik yang berasal dari tanaman secara alami maupun kontaminan selama proses pembuatan ekstrak berupa pasta kental. Berdasarkan pengujian kadar air dan kadar abu terhadap ekstrak pasta kental pada penelitian ini diketahui bahwa bahan tersebut memiliki potensi masa simpan yang panjang serta memiliki kandungan garam anorganik dan mineral penting, dan tidak terjadi kontaminasi kotoran selama pengerjaan proses ekstraksi. Nilai kadar air dan kadar abu akan mempengaruhi nilai rendemen dan ekstrak yang dihasilkan oleh sample. Menurut Ahmed et al. (2010) kandungan air dan kadar abu turut menentukan nilai kompenen lain yang turut terkandung dalam rendemen.

Indonesia memiliki kekayaan sumber bahan kosmetik alami, khususnya tumbuhan kosmetik tradisional yang memiliki peluang untuk dikembangkan sebagai bahan aktif tabir surya (sunscreen). Penentuan khasiat dan mekanisme tabir surya berbahan aktif $S$. alba asal Kota Tarakan pada Tabel. 5 telah teruji bahwa berpotensi menjadi produk sunscreen yang efektif menangkal radiasi sinar UV. Pengujian SPF terdiri atas tahapan: (i) Penapisan kandidat ekstrak bahan aktif (ii) Penentuan nilai SPF berdasarkan kategori tabir surya menurut Damogalad et al. (2013); di mana pada pengujian SPF pada penelitian ini untuk bahan uji bedak dingin, sediaan krim tabir surya, dan krim sunscreen komersial (Tabel 4).

Analisis statistik ANOVA (95\%) berdasarkan nilai $\mathrm{F}$ hitung $<\mathrm{F}$ tabel sehingga $\mathrm{H} 1$ ditolak dan $\mathrm{H} 0$ diterima yakni tidak ada perbedaan nilai SPF di an- 
Tabel 2 Hasil Uji Fitokimia

\begin{tabular}{lll}
\hline Parameter & Penapisan Ekstrak (Pelarut Etanol 70\% & Indikator \\
\hline Alkaloid & + & Terbentuknya endapan jingga merah hingga coklat \\
Fenol & + & Terbentuk endapan hijau hingga hijau biru \\
Flavonoid & + & Terbentuk warna kuning jelas dahulu kemudian larutan kembali seperti semula \\
Saponin & - & Terbentuk busa stabil yang melimpah ketika dikocok \\
Steroid & + & Apabila berwarna merah ungu maka mengandung triterpenoid, dan positif steroid apabila berubah menjadi hijau biru. \\
Tanin & + & Terbentuk warna kuning gelap hingga hitam biru. \\
\hline Keterangan: & + (Positif atau mengandung senyawa yang diuji); dan $-($ negatif atau tidak mengandung senyawa yang \\
diuji) &
\end{tabular}

Tabel 3 Hasil Pengujian Fisik

\begin{tabular}{cccc}
\hline Sampel & Kadar Air (\%) & Kadar Abu (\%) & Rendemen \\
\hline Simplisia kering & $29.21 \pm 3.03$ & $17.99 \pm 2.65$ & - \\
Ekstrak pasta (70\%) & $0.21 \pm 0.02$ & $7.90 \pm 0.01$ & 9.38 \\
\hline
\end{tabular}

Tabel 4 Nilai SPF Ekstrak S. alba

\begin{tabular}{ccc}
\hline Bahan Uji & Nilai SPF & Kategori \\
\hline \multirow{3}{*}{ Bedak Dingin } & 12,29 & Maksimal \\
& 16,41 & Ultra \\
& 8,20 & Maksimal \\
Sediaan Krim & 15,31 & Ultra \\
& 21,86 & Ultra \\
& 10,93 & Maksimal \\
Krim komersil & 11,48 & Maksimal \\
& 16,99 & Ultra \\
& 16,99 & Ultra \\
\hline
\end{tabular}

tara produk tabir surya yang diujikan pada penelitian ini. Berdasarkan katagori kemampuan tabir surya diketahui nilai SPF ketiga produk berbeda yang diujikan pada penelitian ini berkisar di kategori maksimal hingga ultra. Kendali mutu untuk mengkarakterisasi bahan aktif dan pengujian nilai SPF merupakan tahap penting bagi penelitian dan pengembangan produk kosmetik berbahan alami (Darmakusuma, 2014). Penilaian mutu karakteristik $\mathrm{pH}$ pada penelitian ini berkisar antara 6,5-7,5 serta masih layak untuk diaplikasikan pada kulit manusia (Masnec and Pujube, 2008).

\section{SIMPULAN}

Performa sediaan krim tabir surya berbasis bahan baku lokal hutan mangro- ve ( $S$. alba) Kota Tarakan memiliki nidai SPF yang tidak berbeda dengan produk tabir surya lainnya (pupur/bedak dingin dan tabir surya komersil) sehingga berpotensi untuk dikembangkan guna meningkatkan nilai ekonomi masyarakat lokal. Disarankan untuk penelitian selanjutnya dilakukan juga analisis spektroskopi massa dengan menggunakan peralatan GCMS terhadap kandidat ekstrak bahan aktif $S$. alba.

Acknowledgements Terima kasih disampaikan kepada Direktorat Riset dan Pengabdian Masyarakat, Ditjen Penguatan Riset dan Pengembangan, Kemenristekdikti.

\section{Pustaka}

Ahmed, R., Moushumi, S. J., Ahmed, H., Ali, M., Haq, W. M., Jahan, R., and Rahmatullah, M. (2010). Serum glucose and lipid profiles in rats following administration of sonneratia caseolaris (1.) engl.(sonneratiaceae) leaf powder in diet. Advances in Natural and Applied Sciences, 4(2):171-174.

Andayani, R., Maimunah, M., and Yovita, L. (2008). Penentuan aktivitas antioksidan, kadar fenolat total dan likopen pada buah tomat (solanum lycopersicum 1). Jurnal Sains dan Teknologi Farmasi. 
Damogalad, V., Edy, H. J., and Supriati, H. S. (2013). Formulasi krim tabir surya ekstrak kulit nanas (ananas comosus 1 merr) dan uji in vitro nilai sun protecting factor (spf). PHARMACON, 2(2).

Darmakusuma, D. (2014). Pengembangan Kandidat Bahan Aktif Antiphotoaging dari Beberapa Tumbuhan Kosmetik Tradisional Indonesia. $\mathrm{PhD}$ thesis, Institut Pertanian Bogor.

FDCA (2002). Liquid liquid extraction and solid-liquid extraction, institute of thermal process and environmental engineering.

Harvey, D. (2000). Modern analytical chemistry. Boston: McGraw-Hill Companies, Inc.

Herawati, N., Daha, J. L., and Zenta, F. (2011). Potensi antioksidan ekstrak metanol kulit batang tumbuhan mangrove s. alba. J Chemical, 12(1):913.

IMO (2004). Handbook of Pharmaceutical Manufacturing Formulation Semisolid Products. CRC Press.

Lim, S., Cheung, P., Ooi, V., and Ang, P. (2002). Evaluation of antioxidative activity of extracts from a brown seaweed, sargassum siliquastrum. Journal of Agricultural and Food Chemistry, 50(13):3862-3866.

Manalu, R. D. E. (2011). Kadar beberapa vitamin pada buah pedada (sonneratia caseolaris) dan hasil olahannya. Skripsi. Departemen Teknologi Hasil Perairan Fakultas Perikanan dan Ilmu Kelautan Institut Pertanian Bogor. Bogor.

Masnec, I. S. and Pujube, S. (2008). Photoaging. Collagen Antropology, 2:177-180.

Revathi, P., Thirumalaikolundusubramanian, P., Prabhu, N., et al. (2013). Medicinal properties of mangrove plants-an overview. International Journal of Bioassays, 2(12):15971600.

Sayre, R. M., Agin, P. P., LeVee, G. J., and Marlowe, E. (1979). A comparison of in vivo and in vitro testing of sunscreening formulas. Photochemistry and Photobiology, 29(3):559-566.

Svobodová, A., Psotová, J., Walterová, D., et al. (2003). Natural phenolics in the prevention of uv-induced skin damage. a review. Biomed Pap Med Fac Univ Palacky Olomouc Czech Repub, 147(2):137-145.

Wu, S.-B., Wen, Y., Li, X.-W., Zhao, Y., Zhao, Z., and Hu, J.-F. (2009). Chemical constituents from the fruits of sonneratia caseolaris and sonneratia ovata (sonneratiaceae). Biochemical Systematics and Ecology, 37(1):1-5.

Yadav, R. and Agarwala, M. (2011). Phytochemical analysis of some medicinal plants. Journal of phytology. 
